\title{
Wondering about Comparison: Enclaves of Learning in Medieval Europe and South Arabia - Prolegomena to an Intercultural Comparative Research Project
}

\author{
Rutger Kramer and Eirik Hovden*
}

\section{INTRODUCTION}

At first glance, doing comparative research seems relatively easy. Comparison, after all, forms the basis of many of our everyday observations. Any observation can thus be said to be implicitly comparative: against the backdrop of the observer's individual perspective, previous observations and theoretical background, similarities and differences are brought to the fore, which in turn helps formulate an interpretation of what is seen or what is going on. ${ }^{1}$ When such observations turn into a veritable research topic, into a qualitative comparative analysis of various phenomena, the comparison simply becomes more explicit, and turns the similarities and differences between phenomena into the main object of research. However, such an endeavour may become a different challenge entirely when the phenomena under scrutiny - or the researchers involved, for that matter - have such different backgrounds or operate in such different contexts that not just the objects of research become the subject of comparison, but the methods employed to study them as well.

\footnotetext{
* This article is the result of a session held at the IMC 2013 in Leeds: 810 - Visions of Community, VII: Enclaves of Learning - Religion, Ideologies, and Practices in Europe, Arabia, and Tibet. A truly collaborative effort, it has benefitted greatly from the discussions between the authors and members of the VISCOM Work Group on Enclaves of Learning: Mathias Fermer, Johann Heiss, Christian Opitz and Diarmuid Ó Riain. Andre Gingrich, Christina Lutter and Walter Pohl have been instrumental in setting up this work group, and we would like to thank them for their input as well. Finally, the ideas and remarks by Albrecht Diem, Elisabeth Gruber, Gerda Heydemann, Pascale Hugon, Daniel Mahoney, Alexander O’Hara, Steven Vanderputten, Graeme Ward and Veronika Wieser as well as the other team members of the SFB Visions of Community have proven very valuable. VISCOM is a collaborative project between the Austrian Academy of Sciences (ÖAW) and the University of Vienna. The research for this article was funded by the Austrian Science Fund (FWF): F42.

1 A. Gingrich and M. Palmberger, 'Qualitative Comparative Practices: Dimensions, Cases, and Strategies', in U. Flick (ed.), Handbook of Analyzing Qualitative Data (Thousand Oaks, 2013), pp. 94-108, at p. 94-5.
} 
Rutger Kramer and Eirik Hovden

This is one of the points where the SFB Visions of Community, the project within which both authors are working, is breaking new grounds. ${ }^{2}$ Many methodological commentaries written thus far have been based on the premise of comparative research within a single discipline, or on one researcher comparing different cases. ${ }^{3}$ Rather than looking at comparison as a method only, however, this article also explores the necessity to zoom out even further and look at the implications of having different researchers with different backgrounds and agendas come together in an interdisciplinary project where each of them brings one case to the table. The fact that the researchers themselves usually tend to be deeply entrenched into one side of the comparative watershed almost automatically leads to a willingness to explain differences and similarities using the terminology and discourse that comes to mind most readily, from the cultural and academic background of the disciplines involved. ${ }^{4}$ In turn, this engenders most interesting dialogues when attempting to communicate one's findings to another, and makes comparative research a challenge not only on an individual level, but also from a trans-, cross-, or interdisciplinary perspective. ${ }^{5}$ The contributions written for an upcoming Special Issue of History and Anthropology already allow us a glimpse of the challenges ahead, and provide some tentative answers, and the message is clear: when attempting cross-cultural comparative studies, we are not only comparing the subject of research - we are also holding our own expertise against the light. ${ }^{6}$

This article should be seen as a first attempt to build upon these initial observations. More specifically, it aims to highlight the methodological challenges encountered in the course of a comparative analysis of religious communities in various cultures, and to present one of the methodological tools developed in the course of the project. After a short introduction, two case studies will be presented, each coming from the respective specialisations of the authors - one specializing in Early Medieval Europe from a historian's perspective, and the other taking an anthropological approach to Medieval South Arabia. First, in order to present a

\footnotetext{
2 W. Pohl, 'Introduction: Ethnicity, Religion and Empire', in W. Pohl, C. Gantner and R. Payne (eds.), Visions of Community in the Post-Roman World (Farnham, 2012), pp. 1-23. For a further overview of the methodological questions underpinning this project, see the forthcoming collection by A. Gingrich and C. Lutter (eds.), Visions of Community: Comparative Approaches to Medieval Forms of Identity in Europe and Asia, Special Issue: History and Anthropology 25 (2014).

${ }^{3}$ H.-G. Haupt and J. Kocka, 'Comparison and Beyond: Traditions, Scope, and Perspectives of Comparative History' in H.-G. Haupt and J. Kocka (eds.), Comparative and Transnational History: Central European Approaches and New Perspectives (New York and Oxford 2009), 1-32.

${ }^{4}$ What P. Burke, History and Social Theory, 2nd edn (Cambridge, 2005), pp. 2-3 has called a 'dialogue of the deaf', before offering several compromises in the rest of his book.

5 T. Skocpol and M. Somers, 'The Uses of Comparative History in Macrosocial Inquiry', Comparative Studies in Society and History 22 (1980), pp. 174-97, at p. 192.

${ }^{6}$ Cf. B. Rosenwein, 'A Historian in the Amazon', in Gingrich and Lutter (eds.), History and Anthropology (forthcoming).
} 
'European backdrop', the Lotharingian monastery of Saint-Mihiel between its foundation in the late eighth century and the composition of the Chronicon Sancti Michaelis about three centuries later will be described. Far from taking for granted the communal identity of SaintMihiel or the role played by monastic narratives in the construction or consolidation thereof, this section will highlight the role of learning in the self-representation of the community as a dynamic, permeable institution. Additionally, it came into its own at the height of the Carolingian dynasty, right around a time when worldly interests and religious ideas overlapped to a point that to exercise power meant to engage in a certain degree of selfreflection. This could, in short, be considered a time when monastic life and royal ideology were not diametrically opposed, but rather attempted to act in close concord. ${ }^{7}$ While not wholly representative for European monastic life throughout the Middle Ages, the fact remains that knowledge was indeed being fostered in a local context with a view towards supporting a larger social whole also served to delineate its boundaries and anchor the community in the world surrounding it. Then the focus will shift to medieval South Arabia, where we will take a closer look at a type of community that is decidedly un-monastic, and which has proven deceptively hard to grasp by modern researchers and contemporary observers alike. These are hijras, villages inhabited by those who claimed to be descendants of the Prophet Muhammed, acting as centres of Zaydi Islamic religious and scholarly activity in the turbulent tribal context of medieval Yemen. Finally, it will be argued that, while it remains difficult to find common ground between the two fields, the alienation caused by comparative research and the dialogue between the disciplines does allow for the development of fresh perspectives on both types of communities highlighted.

The goal of these two case studies will not be to demonstrate how the communities studied are indicative of universal tendencies in the ideological or practical aspects of religious communal life. ${ }^{8}$ Rather, they are used to propose ways to 'compare the incomparable' without adhering too closely to a singular typology, and shed new light on the weals and woes of comparative studies. ${ }^{9}$ While neither case is wholly representative of their respective region or religion as a whole, wondering about the Carolingian situation will raise questions concerning the South Arabian context, and studying hijras will shed new light on the relation

7 T.F.X. Noble, 'The monastic ideal as a model for empire', Revue Bénédictine 86 (1976), pp. 235-50.

${ }^{8}$ Conversely, J. Osterhammel, 'Transkulturell vergleichende Geschichtswissenschaft', in H.-G. Haupt and J. Kocka (eds.), Geschichte und Vergleich: Ansätze und Ergebnisse international vergleichender Geschichtsschreibung (Frankfurt and New York, 1996), pp. 271-314, at pp. 297-8 posits that transcultural historical comparison is possible precisely because of a supposed 'universalen Einheit der modernen Geschichtswissenschaft'.

${ }_{9}^{9}$ M. Détienne, Comparer l'Incomparable, 2nd edn (Paris 2009), esp. pp. 61-2. 
Rutger Kramer and Eirik Hovden

between monastic communities and the world around them. ${ }^{10}$

\section{WONDERING ABOUT COMPARISON}

When attempting cross-cultural comparison, a logical first step would be to look for phenomena that are at least superficially alike, in order to be able to start the comparative analysis on an empirical level. ${ }^{11}$ Even if the ultimate goal of such a research project is not merely to produce quantifiable results, it seems like a worthwhile opening gambit to do a simple side-by-side comparison first, if only to identify those criteria that seem most likely to yield qualitative results as well. Looks may be deceiving, however, and in an interesting case of a self-fulfilling paradox, the simple fact that one starts a comparative analysis from the notion of existing similarities could already lead to getting trapped in other, deeper preconceived notions - a difficulty that is especially palpable in projects consisting of many researchers with as many academic backgrounds and different conceptualisations of the question at hand.

Within each discipline, there often are fundamental differences in understanding the relation between theory and data. Furthermore, any model developed to make sense of the relations between ideal and reality is inherently artificial, as is the exact context in which each sense of community is used in the sources. ${ }^{12}$ The discussions and tensions over these ideals that we see in our sources and how to implement them is the object of the comparative approach attempted here, not the development of a reduced model of ideal-types of identities or communities. ${ }^{13}$ Choosing which ideals to represent as the important ones for the actors studied also necessitates an explanation of the 'social logic' of the sources through which we

\footnotetext{
${ }^{10}$ T. Skocpol, 'Doubly Engaged Social Science: The Promise of Comparative Historical Analysis', in J. Mahoney and D. Rueschemeyer (eds.), Comparative Historical Analysis in the Social Sciences, Cambridge Studies in Comparative Politics (Cambridge, 2003), pp. 407-28.

${ }^{11}$ For a description of a classical comparative method, including a historical overview and bibliography, see $\mathrm{H}$. Kaelbe, Der historische Vergleich: Eine Einfübrung zum 19. und 20. Jabrhundert, (Frankfurt and New York, 1999), esp. pp. $12-47$.

${ }^{12}$ Noted for early medieval Europe by J.M.H. Smith, Europe after Rome: A New Cultural History 500-1000 (Oxford, 2005), pp. 1-9.

13 A. Gingrich 'Comparative Methods in Socio-Cultural Anthropology Today', in R. Fardon, O. Harris, T.H.J. Marchand, M. Nuttall, C. Shore, V. Strang and R.A. Wilson (eds.), The Sage Handbook of Social Anthropology (London, 2012), pp. 201-14, at pp. 210-11: 'the question of comparability cannot be solved a priori, but depends on the empirical side of a problem.'
} 
gauge these ideas and visions. ${ }^{14}$

It is at this point that Verfremdung may prove to be helpful. It is a nigh untranslatable term, popularized by Bertolt Brecht in his work on epic theatre. In its most condensed form, it entails 'zunächst einfach, dem Vorgang oder dem Charakter, das Selbstverständliche, Einleuchtende zu nehmen und über ibn Staunen und Neugier zu erzeugen (...). Verfremden heißt also Historisieren, heißt Vorgänge und Personen als vergänglich darzustellen'. ${ }^{15}$ According to Brecht, this would be accomplished by, for example, commenting upon the plot as it unfolded, and by continuously reminding his audience that they were essentially spectators who were called upon to actively engage with what they saw. Verfremdung would thus be established by steering an audience's perceptions based on an expectation of their preconceived notions, but all the while reminding them that the narrative is toying with their expectations, and not necessarily with their (f)actual knowledge.

Obviously, this is easier to accomplish in the controlled environment of the theatre than in the infinite complexity of real life; attempting comparative research through interdisciplinary dialogue would imply being author and audience at once. However, the establishment of a Verfremdungseffekt is possible in the controlled environment of a comparative study, and could help break through some of the methodological barriers thrown up by academic tradition and cultural background. Researchers should attempt to create a sense of wonder about their own subject as well as about that of others, by engendering a dialogue and by not taking anything for granted - remaining perpetually aware of what they are doing. ${ }^{16}$

\section{ENCLAVES OF LEARNING}

In the course of comparing Christian and Islamic religious communities, it became clear to

\footnotetext{
${ }_{14}$ G.M. Spiegel, 'History, Historicism and the Social Logic of the Text in the Middle Ages', Speculum 65 (1990), 5986; J.M. Bryant, 'On Sources and Narratives in Historical Social Science: A Realist Critique of Positivist and Postmodernist Epistemologies', British Journal of Sociology 51 (2000), pp. 489-523; D. de Ruyter and J. Conroy, 'The Formation of Identity: The Importance of Ideals', Oxford Review of Education 28 (2002), pp. 509-22.

${ }^{15}$ B. Brecht, Gesammelte Werke in 20 Bänden, 20 vols (Frankfurt, 1967), XV, p. 301; cf. also P. Mecheril, 'Verfremdungseffekte: Brecht, die Migrationsgesellschaft und ihre Kultur', in: S. Hornberg, İ. Dirim, G. LangWojtasik and P. Mecheril (eds.), Beschreiben, Verstehen, Interpretieren: Stand und Perspektiven international und interkulturell vergleichender Erziehungswissenschaft in Deutschland (Münster, 2009), pp. 183-96, who, esp. at pp. 183-86, proposes a similar use of Brecht's concept of Verfremdung.

${ }^{16}$ As similarly argued for the use of histoire croisée by M. Werner and B. Zimmermann, Vergleich, Transfer, Verflechtung: Der Ansatz der Histoire croisée und die Herausforderung des Transnationalen', Geschichte und Gesellschaft 28 (2002), pp. 607-36.
} 
Rutger Kramer and Eirik Hovden

the authors that the term 'monastery' inherently skewed the debate towards a certain degree of Eurocentrism. The term is, after all, bound up with a European Christian tradition. As such, a first step towards Verfremdung would be to drop this as a concept denoting anything but European Christian communities, in order to avoid any sense of familiarity whatsoever. For instance, whereas the etymology of the Latin Christian concept of the monasterium carries with it the notions of isolation and seclusion, in practice they served a host of additional purposes in addition to their ostensibly religious functions. ${ }^{17}$ As such, in the course of the early Middle Ages, they came to represent an increasing number of socio-economic characteristics that clashed with the understanding of a monasterium as an essentially secluded enclave. ${ }^{18}$

Conversely, the word hijra is a combination of two almost similar words. Within the specific Islamic discourse where these communities were most prevalent, hijra refers to the act of emigration, away from an unjust ruler and the act of setting up an enclave where the religious law can be upheld and where a righteous religious ruler can be followed. ${ }^{19}$ In Yemen, towards the end of the eleventh century, we see the term being used for specific villages, towns or centres, and not just for the act of emigration. In the discourse of the local tribes, however, the very similar term hajar (and tabjir r) refers to the concept of neutral territory, which must be protected by the surrounding tribes. A market can be declared as neutral, as well as a town, or the house of a scholarly family or a local judge or mediator. Thus the concept of bijra has combined both these meanings, further embedding these communities in a context that was as influenced by local tribes as it was by over-arching religious visions of community. ${ }^{20}$

Given these significant differences at both emic and etic levels, a logical next step would be to find a descriptor that distils these communities down to comparable proportions. If 'community' is too broad to use, and 'monastery' too specific or Eurocentric, a workable

\footnotetext{
${ }^{17}$ Cf. the lemma in J.F. Niermeyer et al., Mediae Latinitatis Lexicon Minus (Leiden 2002), pp. 702-3.

18 The wide-ranging functions a monastery could attain have been studied for the case of Redon by W. Davies, Small Worlds: The Village Community in Early Medieval Brittany (London, 1988), more generally (but also restricted to one region), see M. Innes, State and Society in the Early Middle Ages: The Middle Rhine V alley 400 - 1000 (Cambridge, 2000).

${ }^{19}$ For the meaning of this term, see: W Madelung, 'The origins of the Yemenite Hijra', [first published in: Arabicus Felix: Luminosus Brittanicus: Essays in Honour of A. F. L. Beeston on his Eightieth Birthday. (ed.), Alan Jones, Ithaca 1991], in Religious and Ethnic Movements in Medieval Islam (Ashgate, 1992); R. B. Serjeant, 'Chapter 5: Șan 'ầ' the protected Hijra', in R.B. Serjeant and R. Lewcock (eds.), San 'ä' An Arabian Islamic City, (London, 1983). For earlier meanings of the term hijra, see also P. Crone, 'The First-Century Concept of Hiğra,' Arabica XLI (1994).

${ }^{20}$ G.-R. Puin, 'The Yemeni Hijrah Concept of Tribal Protection', in T Khalidi (ed.), Land Tenure and Social Transformation in the Middle East, (Beirut, 1984), pp. 145-51; P. Dresch, Tribes, Government, and History in Yemen (Oxford, 1989).
} 
compromise could be to find a conceptualisation that encompasses both the form and (part of) the function of the communities we want to compare. ${ }^{21}$ In this case, 'enclaves of learning' would be such a concept, hard enough to take into account religious and ideological issues as well as practices within and between the communities in question, but soft and 'fuzzy' enough to allow for a low-threshold, common-sense approach to comparison. ${ }^{22}$

In the social sciences and humanities, the concept of enclaves usually designates an entity that is spatially, temporally, and by other socially defined means and borders separated from its wider environment, while simultaneously interacting with it. ${ }^{23}$ By necessity, this phenomenon results in three forms of co-existing and intersecting relations, namely inside each enclave, among various enclaves of similar or related types, and as the main and defining form of the enclave(s) within the world around them. Enclaves may have various purposes - some of them quite explicit and others more implicit, some of them of primary importance and others only of secondary. ${ }^{24}$ One way of analytically distinguishing enclaves across different historical periods and various cultural realms is thus the identification of one or the other of their main purposes, according to the actors living there and to the researchers involved. ${ }^{25}$

Among the many commonalities between our enclaves, the way they guarded, managed, communicated and (especially) used knowledge necessary for their continued existence, as well as the importance of this learning for the religion they represented, gives us a clear 'insider's perspective' of the tensions between ideal and reality they had to cope with. This, in turn, allows us to more fully understand the visions of community underpinning the existence of the hodgepodge of the - sometimes admittedly bizarre - people we study. As David Ganz has pointed out, studying learning and education highlights 'the tensions

\footnotetext{
${ }^{21}$ Although these communities are not necessarily 'institutions' as such, many ideas proposed by K. Thelen, 'How Institutions Evolve: Insights from Comparative Historical Analysis', in J. Mahoney and D. Rueschemeyer (eds.), Comparative Historical Analysis in the Social Sciences, Cambridge Studies in Comparative Politics (Cambridge, 2003), pp. 208-40, at pp. 230-35 have been very useful for the current study as well.

${ }^{22}$ Cf. on this use of 'fuzzy concepts', R. Belohlavek and G.J. Klir, 'Fuzzy Logic: A Tutorial', in R. Belohlavek and G.J. Klir (eds.), Concepts and Furzy Logic (Cambridge MA, 2011), pp. 45-88, and also, in the same volume and by the same authors, 'Fallacious Perceptions of Fuzzy Logic in the Psychology of Concepts', pp. 121-48.

${ }^{23}$ For example, see E. Vinokurov, A Theory of Enclaves (Lanham MD, 2007); even though his study is primarily based on a more political/territorial interpretation of enclaves (and exclaves) as part of a state ('true enclaves'), his observations on their openness and functioning within a larger social whole are applicable to non-national enclaves as well.

${ }^{24}$ J. Peoples and G. Bailey, Humanity: An Introduction of Cultural Anthropology (Stamford CT, 2009; 9th edition 2012), pp. 27-9.

${ }_{25}$ The authors would like to thank Prof. Andre Gingrich for his helpful remarks on this matter, and his help in formulating this description.
} 
Rutger Kramer and Eirik Hovden

between spiritual fulfilment and resistance to (...) authority'. ${ }^{26}$ Although the existence of monasteries in the early Middle Ages was often ideologically justified by referring to their mastery over the Power of Prayer, they also functioned as havens of education and managers of knowledge. ${ }^{27}$ This function connected their idealism to their more earthly concerns - and whenever tensions occur between the two, boundaries are drawn, communities grow together, and enclaves spring into existence. ${ }^{28}$ For the situation in early Medieval Europe, these tensions and their role in shaping and re-shaping monastic communal identities have been the subject of many multi-faceted studies, approaching this problem from as many angles as the source material would allow. ${ }^{29}$ This rich research tradition serves as a jumpingoff point for the current research project as well, which aims to expand the conclusions drawn from European studies by applying them in a multi-cultural setting - and vice versa. It is for this reason that knowledge, learning and tradition have been singled out here, and the role these play in the ideologies described by contemporary actors, we can attempt comparisons that transcend the boundaries of time and cosmology, between European monasteries and their cross-cultural counterparts. Looking at the ways the actors in religious communities communicated their ideals and practices to subsequent generations is one way to accomplish this. ${ }^{30}$ As will be argued in this article, this could be a fruitful, if challenging, avenue of comparison.

The lack of a clear definition for 'enclaves of learning' as a concept is as much a blessing as a

${ }^{26}$ D. Ganz, 'Conclusion: Visions of Carolingian Education Past, Present, and Future', R.E. Sullivan (ed.), The Gentle Voices of Teachers: Aspects of Learning in the Carolingian Age (Columbus OH, 1995), pp. 261-83.

${ }^{27}$ M. de Jong, 'Carolingian Monasticism: The Power of Prayer', in R. McKitterick (ed.), The New Cambridge Medieval History II: c. 700 - c. 900 (Cambridge, 1995), pp. 622-53.

${ }^{28}$ Cf. for the case of ethnic groups, F. Barth, 'Introduction', in F. Barth (ed.), Ethnic Groups and Boundaries: The Social Organization of Culture Difference (Long Grove IL, 1989), pp. 9-38, at pp. 29-30.

${ }^{29}$ See, among many others, J. Semmler, 'Benedictus II: una regula - una consuetudo', in W. Lourdaux and D. Verhelst (eds.), Benedictine Culture 750-1050, Mediaevalia Lovaniensia 1 (Leuven, 1983), pp. 1-49, as well as other works by this author - but cf. D. Geuenich, 'Kritische Anmerkungen zur sogenannten "anianischen Reform"', in D.R. Bauer, R. Hiestand, B. Kasten and S. Lorenz (eds.), Mönchtum - Kirche - Herrschaft 750-1000: Josef Semmler zum 65. Geburtstag (Sigmaringen 1998), pp. 99-112; R. Kottje, 'Einleitung: monastische Reform oder Reformen?', in R. Kottje and H. Maurer (eds.), Monastische Reformen im 9. und 10. Jabrbundert, Vorträge und Forschungen 38 (Sigmaringen 1989), pp. 9-13 as well as the other contributions it that volume; J. Contreni, 'Inharmonious Harmony: Education in the Carolingian World', Annals of Scholarship 1 (1980), pp. 81-96; A. Diem, 'Monks, Kings, and the transformation of sanctity: Jonas of Bobbio and the End of the Holy Man', Speculum 82 (2007), 521-559, and on the Development of Monastic Exclusivity through Chastity, A. Diem, 'Das monastische Experiment: die Rolle der Keuschheit bei der Entstehung des westlichen Klosterwesens', Vita Regularis 24 (Münster 2005).

${ }^{30}$ Interestingly, the title of Ismā' 11 al-Akwa's seminal lexicographic work on hijras is Yemen could be translated as 'Hijras of learning and their enclaves [of learning], in Yemen' al-Akwa', Ismā'îl b. 'Alī. Hijar al- 'ilm wa-ma 'äqilubu fì al-Yaman (Beirut, 1995). For the word 'ma'qil', see Hans Wehr: Ma'qil, pl. ma'äqil: 'Refuge, sanctuary; stronghold, fortress, fort [...]' H. Wehr, A dictionary of modern written Arabic: (Arabic-Engl.) (ed.) J.M. Cowan, 1994) p. 737. 'Enclave' has also been used to designate European monasteries, for example by M.M. Hildebrandt, The External School in Carolingian Society (Leiden 1992), at p. 50, as well as Buddhist institutions (in this case in Japan): B. Faure, Visions of Power: Imagining Medieval Japanese Buddhism (Princeton, 1996), at pp. 194-95. 
curse in this respect. ${ }^{31}$ On the one hand, it does leave the object of research open to intuitive selection by the researchers involved, which requires intensive cooperation and a willingness on the part of everybody to familiarize him- or herself with the contexts presented by their colleagues and the ways data models and theories have been connected. 'Learning', after all, does not apply solely to the transfer of knowledge per se. It encompasses a wide range of interdependent aspects, such as the political or societal ideologies expressed in the knowledge possessed; 32 the religious contents and ideas steering the learning itself; 33 and of course the practices involved in both processing and using the knowledge gained. ${ }^{34}$ On the other hand, however, it allows for comparisons that go beyond notions that steer initial impressions, and opens up possibilities to include communities that defy a more classical, narrow 'monastic' definition. ${ }^{35}$ Maintaining a certain degree of abstraction, of Verfremdung, may complicate the acquisition of definitive results, but it does catalyse an ongoing discussion into the nature of the communities under scrutiny - and as we will see, it is from the discussions and tensions that the most valuable insights may arise.

\section{A SHINING EXAMPLE: THE MONKS OF SAINT-MIHIEL ON THE VIA REGIA}

To some extent, both types of enclave under scrutiny have been founded on a religious, ideological basis, and it is precisely such ideals that impinge upon our preconceptions when attempting comparative research at all. With all that in mind, it is now time to turn to the first case study, in which we will take a closer look at the self-representation of the monastery of Saint-Mihiel as an 'enclave of learning'. Saint-Mihiel, situated in the north-east of present-day France, seems especially suited to the purpose of this study. Firstly, it was founded right around the time that the Carolingians took power, and more or less grew

\footnotetext{
${ }^{31}$ Cf. the remarks by D.E. Apter, 'Comparative Studies: A Review with some Projections', in I. Vallier (ed.), Comparative Methods in Sociology: Essays on Trends and Applications (Berkeley 1971; 2nd edition 1973), pp. 3-15, at pp. 910.

32 J.P. Gee, Social Linguistics and Literacies: Ideology in Discourses (London and New York 1990; 3rd ed. 2008), pp. 27-30.

${ }^{33}$ J.J. Contreni, 'The Pursuit of Knowledge in Carolingian Europe', in: Sullivan (ed.), Gentle Voices of Teachers, pp. 106-41.

34 A distinction that was especially important in the Buddhist context: J. Robson, "Neither too far, nor too near": The Historical and Cultural Contexts of Buddhist Monasteries in Medieval China and Japan', in J.A. Benn, L. Meeks and J. Robson (eds.), Buddhist Monasticism in East Asia: Places of Practice, Routledge Critical Studies in Buddhism 53 (Abingdon and New York, 2010), pp. 1-17, at, p. 3; or for a more pro-active use of knowledge: B. Rosenwein, 'Feudal War and Monastic Peace: Cluniac Liturgy as Ritual Aggression', Viator 2 (1971), pp. 129-57 or L.K. Little, Benedictine Maledictions: Liturgical Cursing in Romanesque France, (Cornell, 1993).

${ }^{35}$ G.E. Swanson, 'Frameworks for Comparative Research: Structural Anthropology and the Theory of Action', in Vallier (ed.), Comparative Methods in Sociology, pp. 141-201.
} 
Rutger Kramer and Eirik Hovden

alongside the dynasty itself. Thus, although it could not boast a long and venerable history, such as, for example, the monasteries of Corbie or Fulda, it had to develop its communal identity in the context of the Carolingian reform movement. ${ }^{36}$ Conversely, unlike monasteries such as Aniane or Kornelimünster, Saint-Mihiel was not founded in the wake of this same reform movement, but became an intrinsic part of it all the same thanks to the writings of Smaragdus, one of its most important abbots. ${ }^{37}$ In his writings, he managed to describe his own ideals about monastic life - and Christian life in general - in such a way as to reflect upon the life in his own community and the empire within which it functioned. ${ }^{38}$ Studying these texts as well as their Nachleben will therefore not only enable us to probe deeper into the conception of monastic life of monasteries in the Carolingian age, but also give us a European example which may serve as a benchmark for a comparative look at the hijras of South Arabia.

Saint-Mihiel was founded by the Lotharingian count Wulfoald in the early eighth century, after relics of Saint Michael had almost literally taken root in the region by attaching themselves to a tree. ${ }^{39}$ The monastery rose to prominence not only thanks to its central position in the Carolingian Empire, close to the city of Metz, but also by its association with the court. ${ }^{40}$ This was already palpable in 755, when Pippin III donated the still-growing cell to the monastery of Saint-Denis in Paris, but only came to full fruition when Smaragdus, ecclesiastical advisor of Charlemagne and Louis the Pious, was made abbot. ${ }^{41}$ Through this association, as well as through the acquisition of some important relics, the monastery remained a favourite of kings, bishops and nobility, and persisted as a reasonably prosperous foundation until its dissolution in 1790.

\footnotetext{
${ }^{36}$ See D. Ganz, Corbie in the Carolingian Renaissance, Beihefte der Francia 20 (Sigmaringen, 1990); J. Raaijmakers, The Making of the Monastic Community of Fulda, c.744 - c.900, Cambridge studies in medieval life and thought 4.83 (Cambridge, 2012).

${ }^{37} \mathrm{On}$ these monasteries, see especially W. Kettemann, Subsidia Anianensia: Überlieferungs- und textgeschichtliche Untersuchungen zur Geschichte Witiza-Benedikts, seines Klosters Aniane und zur sogenannten 'anianischen Reform' (Duisburg 2000); N. Kühn, Die Reichsabtei Kornelimünster im Mittelalter. Geschichtliche Entwicklung, Verfassung, Konvent, Besitz, Veröffentlichungen des Stadtarchivs Aachen 3 (Aachen, 1982)

${ }^{38} \mathrm{~A}$. Dubreucq, 'Smaragde de Saint-Mihiel et son temps: enseignement et bibliothèques à l'époque carolingienne', in Mélanges de la Bibliothèque de la Sorbonne 7 (1986), pp. 7-36.

${ }^{39}$ As related in the Chronicon Sancti Michaelis in pago Virdunensi, cc. 2-3, ed. G. Waitz, MGH Scriptores 4 (Stuttgart, 1841), pp. 78-86, at pp. 79-80; trans. by M. Gaillard, 'Traduction de la "Chronique de Saint-Mihiel" (XIe siècle)', in S. Gougenheim (ed.), Retour aux Sources: Textes, Études et Documents d'Histoire Médiévale offerts à Michel Parisse (Paris, 2004), pp. 987-1013.

40 O.G. Oexle, 'Die Karolinger und die Stadt des heiligen Arnulf, Frühmittelalterliche Studien 1 (1967), pp. $250-364$.

${ }^{41}$ It was under Smaragdus, for example, that the monastery received an imperial immunity charter: A. Lesort, Chronique et Chartes de l'Abbaye de Saint-Mibiel, 4 vols, Mettensia: Mémoires et Documents Publiés par la Société Nationale des Antiquaires de France 6 (Paris, 1909-1912), p. 320. On the meaning of such charters in the time of Louis the Pious, see T. Kölzer, Kaiser Ludwig der Fromme (814-840) im Spiegel seiner Urkunden (Paderborn, 2005).
} 
The timing is important. From the second half of the eighth century onwards, in the wake of the Carolingian takeover of the Merovingian throne, the new rulers had embarked on a program of ecclesiastical reforms that was as comprehensive as it was ambitious. ${ }^{42}$ What was at stake was a complete re-definition of what it meant to be a good Christian in a good 'Christian Empire', from the top of the hierarchy all the way down to the lowliest parishioner. ${ }^{43}$ Kings and judges, abbots and bishops, monks and priests all found their positions appraised, and were called upon to reflect upon their own responsibilities and their function in the greater scheme of things. These reforms arguably reached their apex in the last decades of the reign of Charlemagne - set in motion with the issuing of the famous Admonitio Generalis of 789 - and the first half of the reign of Louis the Pious, who actually incorporated a considerable amount of monastic ideology in his 'model for empire'. ${ }^{44}$ However, they should really be seen as a continuous process of negotiations between prelates and nobility, with the court setting itself up as the ultimate arbiter in the best tradition of the Christian Roman emperors of Late Antiquity. ${ }^{45}$ Needless to say, education, learning and knowledge stood at the centre of this improvement movement.

The Carolingian ecclesiastical reform efforts did not leave Saint-Mihiel unaffected either. At a most basic level, the monks of this community, like the inhabitants of many other monasteries in the realms, were prompted to evaluate their position, construct their communal identity, and consolidate their place in the Carolingian Empire. Doing so also involved interacting with others who were in the same boat: the community of Saint-Mihiel was involved in large synods where the new world order would be decided, and Smaragdus, its most visible abbot, even weighed in on questions that affected the theological

\footnotetext{
42 Among the many studies of this movement, see R. McKitterick, The Frankish Church and the Carolingian Reforms 789 895 (London, 1977). For the specifically monastic context, see the many works by J. Semmler, for example 'Benediktinische Reform und kaiserliches Privileg: Die Klöster im Umkreis Benedikts von Aniane', in Società, Istituzioni, Spiritualità: Studi in onore di Cinzio Violante, Centro Italiano di Studi sull'Alto Medioevo: Collectanea 1 (Spoleto 1994), pp. 787-832; J. Semmler, 'Benedictus II', but see also D. Geuenich, 'Kritische Anmerkungen zur sogenannten "anianischen Reform”, in: D.R. Bauer et al. (eds.), Mönchtum - Kirche - Herrschaft 750-1000: Josef Semmler zum 65. Geburtstag (Sigmaringen 1998), pp. 99-112.

${ }^{43}$ G. Bührer-Thierry, 'Pensée hierarchique et differenciation sociale: quelques reflexions sur l'ordonnancement des societes du haut Moyen Âge', in D. Iogna-Prat, F. Bougard and R. Le Jan (eds.), Hiérarchie et Stratification Sociale dans l'Occident Médiéval 400-1100, Collection Haut Moyen Âge 6 (Turnhout 2008), pp. 363-90, at p. 369; Carine van Rhijn, 'Priests and the Carolingian Reforms: The Bottlenecks of Local correctio', in R. Corradini, R. Meens, C. Pössel and P. Shaw (eds.), Texts and Identities in the Early Middle Ages (Wien, 2006), pp. 219-38.

${ }^{44}$ Noble, 'The monastic ideal as a model for empire'.

45 P.F. Bang, 'Court and State in the Roman Empire: Domestication and Tradition in a Comparative Perspective', in J. Duindam, T. Artan and M. Kunt (eds.), Royal Courts in Dynastic States and Empires: A Global Perspective, Rulers \& Elites 1 (Leiden, 2011), pp. 103-29; D.A. Bullough, 'Der Kaiseridee zwischen Antike und Mittelalter', in C. Stiegemann and M. Wemhoff (eds.), Kunst und Kultur der Karolingerzeit: Karl der Große und Papst Leo III. in Paderborn 3 (Mainz, 1999), pp. 36-46.
} 
Rutger Kramer and Eirik Hovden

underpinnings of the empire as a whole. ${ }^{46} \mathrm{And}$, as explained above, each of their actions at each of these levels would have affected their vision of the community they lived in as well. Thus, one of the paths they followed to find their way in this bewildering world was to set themselves up as an exemplary 'enclave of learning' - a move that proved so influential that it was still tangible centuries later. ${ }^{47}$

We can trace the history of Saint-Mihiel through a late twelfth-century cartulary, which contains documents (some falsified) going back to the eighth century, and a small Chronicle that is included in the cartulary, but which was written sometime between 1036 and 1050, during the abbacy of Nanterus. In fact, the chronicle reads more like a Gesta Nanteri, as almost two-thirds of the text is taken up by his abbacy, the furta sacra he undertook, and the miracles performed by the relics he procured from Rome. ${ }^{48}$ It is the story of a community that was no longer centrally positioned in the empire, but ended up in a contested border region, ruled by a count whose allegiance to the emperor was tenuous at best. Religious life was still in full development: the influence of the Cluniac model was making itself known, for example, and preludes to the Gregorian Reform were becoming tangible through the activities of people like Pope Leo IX - himself a Lotharingian. ${ }^{49}$ In this context, the actions of Nanterus were vital for the well-being of Saint-Mihiel. Apart from the relics he obtained, he also secured new lands by interceding with the emperor, and thus breathed new life into the community. In the process, he bridged the growing divide between Church and empire, by claiming spiritual support from Rome and material support from the emperor, Conrad II. ${ }^{50}$ This is the story of a community still negotiating the lay of the land, carefully manoeuvring between local nobility, imperial power, and papal authority. It also was the story of a venerable institution with a long history, though, and that is the narrative arc contained in the first chapters.

\footnotetext{
${ }^{46}$ M. Ponesse, 'Smaragdus of St. Mihiel and the Carolingian Monastic Reform', in: Revue Bénédictine 116 (2006), 367392. More generally, see F. Rädle, Studien zu Smaragd von Saint-Mibiel, Medium Aevum 29 (München, 1974).

${ }^{47}$ The dynamism of the Carolingian church was already noted in Raymund Kottje, 'Einheit und Vielfalt des kirchlichen Lebens in der Karolingerzeit', Zeitschrift für Kirchengeschichte, Vierte Folge XIV 76 (1965), 323-342. See also M. de Jong, 'Charlemagne’s Church', in: J. Story (ed.), Charlemagne: Empire and Society (Manchester, 2005), 103-136.

48 Chronicon Sancti Michaeli, cc. 9-33, at pp. 82-86; cf. P. Geary, Furta Sacra: Thefts of Relics in the Central Middle Ages, 2nd edn (Princeton, 1990), p. 150.

${ }^{49}$ M. Gaillard, D'Une Réforme à l'Autre (816-934): Les Communautés Religieuses en Lorraine à l'Époque Carolingienne (Paris, 2006); P.G. Jestice, Wayward Monks and the Religious Revolution of the Eleventh Century, Brill's Studies in Intellectual History 76 (Leiden, 1997), 170-209.

${ }^{50}$ The difficulties of the many conflicts in the border region even led to the plundering of the monastery by imperial troops in 1033: H. Wolfram, Conrad II, 990-1039: Emperor of Three Kingdoms (Munich, 2000; trans. D.A. Kaiser, University Park PA, 2006), pp. 242-243.
} 
After calculating the date of foundation, the author tells how the sanctuary that emerged around the relics of Saint Michael was endowed with the possessions of Wulfoald, and how the monks are granted a royal immunity, first by Pippin, and later by Charlemagne. The author then states that 'Concerning the abbots leading this place before the time of Charlemagne, we have found nothing written', so the story picks up in the late-eighth century, when another relic is added to the monastery's collection. ${ }^{51}$ Conveniently enough, the author never mentions the charter of 755 in which Saint-Mihiel is conferred to the protection of Fulrad of Saint-Denis after Wulfoald had been convicted of treason (a charter that is only extant in the archives of Saint-Denis, for obvious reasons). ${ }^{52}$ A holy place is born, with prestigious relics demonstrating divine favour, and local and supra-regional powerbrokers showing their support. ${ }^{53}$

Then, Smaragdus, whose reputation and merits shine 'like a precious gem', was elected abbot. ${ }^{54}$ The author continues:

'It would be superfluous to sing his praise and glory, because, even if we remain silent, the books he edited are sufficiently eloquent, and they show with a bright light how ingenious he was in matters divine and secular. Above all, that book called the Diadema Monachorum shines as an example of his piety and sanctity. In fact, he could not have given such a lucid teaching on virtues if he had not himself had the experience of their practice'. .55

What is more, Smaragdus, 'prudent and discerning' as he was, considered that the hilltop sanctuary would be too difficult to reach, and established a second monastery in the Meuse valley, the place we now know as Saint-Mihiel, although the relics of Saint Michael remained on their hilltop. 'However', the author justified the decision, 'this change of scenery was not contrary to the archangel's will, (...) because, although his angelical purity usually chooses high places for his veneration, (...) we reckon he would not deem it unworthy for humans who require places more apt for their condition, so that they may implore the intercession of

\footnotetext{
${ }^{51}$ Chronicon Sancti Michaeli, cc. 3-4, at p. 80: 'De abbatibus autem qui loco praefuerunt ante tempora Caroli Magni nibil dictum reperimus'.

${ }^{52}$ Gaillard, 'Traduction', 989-991.

${ }^{53}$ For a comparable but more extensive study on the making of Redon in Brittany, see J.M.H. Smith, 'Aedificatio sancti loci: the making of a ninth-century holy place', in: F. Theuws, M. de Jong and C. van Rhijn (eds.), Topographies of Power in the Early Middle Ages, The Transformation of the Roman World 6, (Leiden, 2001), pp. 361-396.

${ }^{54}$ Chronicon Sancti Michaeli, c. 5, at pp. 80-81: 'Qui Smaragdus revera praesagio se sui nominis conformans, inter celebres sui temporis viros ut pretiosa gemma meritis et fama resplenduit...'.

55 Chronicon Sancti Michaeli, c. 5, at pp. 80-81: ‘... de cuius landibus et gloria nos aliud garrire superfluum est, cum eas nobis tacentibus libri quos edidit sufficienter eloquantur - in quibus luce clarius apparet, quam perspicaci ingenio in divina et saeculari claruerit-praecipueque liber ille, quem Diadema monachorum intitulavit, religiositatem sanctitatemque eius evidentissime declaret. Non enim tam lucidam de virtutibus doctrinam dare posset, nisi ipsarum in sese naturam exercitiorum experientia persensisset.
} 
Rutger Kramer and Eirik Hovden

the angels in heaven'. ${ }^{56}$ According to his epitaph, Smaragdus had in effect made Saint-Mihiel 'suitable for humans', and created a place from where they could learn how to reach the city on the hill only six miles away. ${ }^{57}$

In this sense, it is interesting that the author picked the Diadema Monachorum as the quintessential work by Smaragdus. His entire corpus was actually much larger, and also included a treatise on the Ars Grammatica by Donatus; ${ }^{58}$ a Commentary on the Regula Benedicti, explaining how the (re)implementation of the 'original' Regula and the accompanying Carolingian reforms should be incorporated into local monastic traditions; ${ }^{59}$ and a work commonly seen as an early example of a Fürstenspiegel, the Via Regia. ${ }^{60}$ Of these, the last two, together with the Diadema Monachorum, form something of a trilogy on monastic life - or even on Christian life in general. ${ }^{61}$

First, the Via Regia uses the road as a metaphor for the education of people in a position of authority. ${ }^{62}$ The Via Regia 'is called holy by the prophet [Isaiah]', and would enable those taking heed of its teachings to ascend towards Heaven. ${ }^{63}$ As also used in several other moral treatises at the time, the Biblical Via Regia was a road through enemy territory that the people of Israel wished to use (peacefully) - it is not a road for kings exclusively, but a road that is kept safe through the ability to govern one's self, which one may accomplish by following the 'way, truth and life' represented by Christ. ${ }^{64}$

\footnotetext{
${ }_{56}$ Chronicon Sancti Michaeli, c. 5, at p. 81: 'Non enim videtur nobis vir prudens contra archangeli voluntatem egisse, qui priorem sibi locum in monte delegit, quia angelica puritas, etsi alta venerationi suae loca eligere soleat ac se a terrena conversatione remotam significet, non tamen indignatur mortalibus, si competentia loca suae conditioni requirant, dummodo angelica suffragia in altis sibi exspectanda cognoscant.

${ }^{57}$ Epitaphium Smaragdi, Chronicon Sancti Michaeli, c. 5, at p. 81: 'Qui locus humanis quod erat minus usibus aptus / Haud procul binc sedem transtulit ille suam'.

${ }^{58}$ Smaragdus, Liber in partibus Donati, ed. B. Löfstedt, L. Holtz and A. Kibre, Corpus Christianorum Continuatio Medievalis 68 (Turnhout, 1986).

59 Smaragdus, Expositio regulae Sancti Benedicti, ed. A. Spannagel and P. Engelbert, Corpus Consuetudinum Monasticarum 8 (Siegburg, 1974) 3-337; trans. D. Barry, Smaragdus of Saint-Mibiel: Commentary on the Rule of Saint Benedict, Cistercian Studies Series 212, (Kalamazoo, 2007).

${ }^{60}$ Smaragdus, Via Regia, J.P Migne ed., Patrologia Latina 102 (Paris, 1852), cols. 931-970; trans. J. Leclercq, Smaragde: La Voie Royale - Le Diadème des Moines (La Pierre-qui-Vire, 1950).

${ }^{61}$ Cf. M.D. Ponesse, 'Standing distant from the fathers: Smaragdus of Saint-Mihiel and the reception of early medieval learning', Traditio 67 (2012), 71-99; J. Bovendeert, 'Royal or monastic identity? Smaragdus' Via regia and Diadema monachorum reconsidered', in Corradini et al. (eds.), Texts and Identities, 239-252.

${ }^{62}$ On the Via Regia in general, see O. Eberhardt, Via Regia: der Fürstenspiegel Smaragds von St. Mibiel und seine literarische Gattung (München, 1977).

${ }^{63}$ Smaragdus, Via Regia, Epistola nuncupatoria, 934D: 'Via etenim regia est, quae per prophetam vocatur sancta [Isaiah XXXV.8]'

${ }^{64}$ For example, Pseudo-Cyprianus, De XII Abusivis Saeculi, c. 12, ed. S. Hellmann, Texte und Untersuchungen zur Geschichte der altchristlichen Literatur 34.1 (Leipzig, 1909), p. 59; Alcuin, Epistola 117, ed. E. Dümmler, MGH Epistolae Karolini aevi 2, (Berlin, 1895), pp. 172-173; Hrabanus Maurus, Epistola 42, ed. E. Dümmler, MGH
} 
As such, the Via Regia was not so much a mirror for princes per se, but rather a reflection on the perfect Christian life, the life of those walking on the 'king's highway' as a metaphor for the difficult road to perfection made accessible through the Regula Benedicti. ${ }^{65}$ It is therefore hardly surprising that similar imagery was used as a recurring motif in the Commentary to show how the Regula is a road, a 'narrow path to life', a 'via sancta' that enables monks to 'climb swiftly to the golden realms'. ${ }^{66}$ The Rule, according to Smaragdus, was called a 'via regia', which 'regulates the monk's mind'. ${ }^{67}$

If the Commentary was composed as a way of showing how the regular life ought to be lived in individual monasteries, and the Via Regia was meant to demonstrate how all Christians have a responsibility to themselves to become worthy of walking the King's Highway, the Diadema Monachorum continued this train of thought by showing how it is the internalization of Christian teachings that allowed more experienced monks to acquire a diadema - a symbol of spiritual authority conferred upon people who are able 'to feel invisible, spiritual joy about the chastity of the body and the cleanliness of the heart' just as 'we rejoice externally about the consecration of an altar in a house of God'. ${ }^{68}$ Although it is clear that this work was aimed primarily at a monastic audience, Smaragdus seems to continuously imply that this diadema was not exclusively meant for monks. It was meant for all good Christians - but monks had the opportunity to live in circumstances where they could truly aspire to live a perfect life, and thus serve as an example to those around them. One way to accomplish this was through prayer, described as a 'matter of the heart, not of the lips' - which might in turn be accomplished by constant (self-) education.

In the Prologue to the Regula, Benedict characterized monasteries as 'Schools for the Lord's

Epistolae Karolini aevi 3 (Berlin, 1899), 481-487; and Smaragdus himself, Expositio, c. 1: 'ECCE PIETATE SUA DEMONSTRAT NOBIS DOMINUS VIAM VITAE: Ipse ergo Dominus, ut praedictum est, factus est via, veritas, et vita. Via scilicet regia, ut per cum gradientes, non declinemus ad dexteram, aut ad sinistram, sed ad vitam, quae ipse est, perveniamus aeternam' (the highlighted text is quoted by Smaragdus from the corresponding chapter in the RB). Cf. H.-H. Anton, Fürstenspiegel und Herrscherethos in der Karolingerzeit, Bonner historische Forschungen 32 (Bonn, 1968), p. 172, where he points out

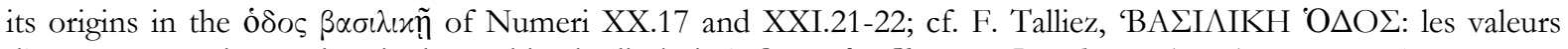
d'un terme mystique et le prix de son histoire littéraire', Orientalia Christiana Periodica 13 (1947), pp. 199-254.

${ }^{65}$ Cf. on this genre in general R. Stone, Morality and Masculinity in the Carolingian Empire, Cambridge Studies in Medieval Life and Thought, Series 4 vol. 81, (Cambridge, 2012), pp. 27-68; L.K. Born, "The "specula principis" of the Carolingian Renaissance', Revue belge de Philologie et d'Histoire 12 (1933), pp. 583-611, at p. 610. Cf. A. Diem, 'Inventing the Holy Rule: some observations on the history of monastic normative observance in the Early Medieval West', in H.W. Dey and E. Fentress (eds.), Western Monasticism ante litteram: The Space of Monastic Observance in Late Antiquity and the Early Middle Ages, Disciplina Monastica 7 (Turnhout, 2011), 53-84.

${ }^{66}$ Smaragdus, Expositio, Praefatio: 'Relligione [sic] pia vitae perquirere callem / Scandere quo valeat aurea regna celer'.

${ }^{67}$ Smaragdus, Expositio, Praefatio: 'Patribus a nostris in sacro carmine legis / Regia rectegradis dicitur ista via'. And: 'Temperet interea monachi discretio mentem / Et via per medium regia ducat eum'.

${ }^{68}$ Smaragdus, Diadema Monachorum, c. 100: 'Et quomodo visibiliter de templi altaris consecratione gaudemus, sic invisibiliter de corporis castita e vel animi puritate spirituale gaudium habere mereamur'. 
Rutger Kramer and Eirik Hovden

service', and Smaragdus comments that:

'...just as boys in a school learn - and are disciplined - what is necessary for them and grasp what profits them in the future, so monks in the school of a regular monastery must learn both what enables them to live uprightly in the present, and what may make them happy in the future; and they must put this into practice' ${ }^{69}$

As he further explains in his Diadema, the understanding thus gained can be deepened by praying and reading, which opens a dialogue with God. 'When we pray, we speak to God', Smaragdus states, 'but when we read, God speaks to us'. ${ }^{70}$ And so one continues to learn a 'well-ordered way of right living', 'because sacred scripture in some way grows with its readers: it becomes familiar to its unskilled readers, and yet the learned always find new things there'. ${ }^{71}$

Taken together, these three works represent Smaragdus' reaction to the tensions experienced by the Carolingian ecclesiastical reform movement, thanks to which monasteries could no longer simply rely on their status as Christian communities par excellence. They would have to bring more to the table, and it was up to Smaragdus to show how monks, through learning and education, should become enclaves unto themselves, with their 'internal cloister' strengthened by the purity of their demeanour. ${ }^{72}$ As if living up to a strictly monastic idealism was not difficult enough, they would now have to carve out a place as Christian communities in a thoroughly Christianized empire - which had in turn partly modelled itself on the ideal represented by the monasteries upon which it was founded. It is hardly surprising that these tensions still echoed through the Meuse Valley two centuries later, and that the author of the Chronicle of Saint-Mibiel singled out the work of Smaragdus as one of the cornerstones of his community. In fact, between Smaragdus and Nanterus, no one abbot seems to be worthy of his particular attention - he merely lists their names. To the author, it was Nanterus who ushered Saint-Mihiel into the new millennium, but the true strength of

\footnotetext{
${ }^{69}$ Smaragdus, Expositio, Praefatio: 'Ergo sicut in schola pueri cum disciplina, quae illis necessaria sunt discunt, et quae in futuro prosint capiunt: ita et monachi in monasterii regularis schola, et quae eos in praesenti boneste vivere faciant, et quae in futuro felices reddant, discere sagaciter et efficaciter debent implere'.

${ }^{70}$ Smaragdus, Diadema Monachorum, c. 3, at col. 597D: 'Nam cum oramus, ipsi cum Deo loquimur, cum vero legimus, Deus nobiscum loquitur?.

${ }^{71}$ Smaragdus, Diadema Monachorum, c. 3, at cols. 598A: 'Scriptura sacra aliquo modo cum legentibus crescit, a rudibus lectoribus quasi recognoscitur, et tamen a doctis semper nova reperitur?

72 As explained in M. de Jong, 'Internal cloisters: the case of Ekkehard's Casus sancti Galli, in W. Pohl and H. Reimitz (eds.), Grenze und Differenz im frühen Mittelalter, Forschungen zur Geschichte des Mittelalters 1 (Wien, 2000), pp. 209-221; cf by the same author also 'Imitatio morum: the cloister and clerical purity in the carolingian world', in: M. Frassetto (ed.), Medieval Purity and Piety: Essays on Medieval Clerical Celibacy and Religious Reform (New York 1998), pp. 49-80
} 
the monastery was within the community of monks, and the heart and soul of that community was shaped thanks to Smaragdus. His role in the Chronicle was a vital step towards Saint-Mihiel's development into an 'enclave of learning', which, as Smaragdus explained, need not be limited to one single person or one individual community:

'...if the dwelling of one person is properly called a monastery (...) we must ask why the dwelling of many persons established in one place is also called a monastery, unless perhaps $(. .$.$) it is because there is one faith, one baptism, one heart and one soul [cf.$ Ephesians IV.5] in all monks who are living good and upright lives, just as there was earlier in the religion of those who believed rightly and lived good lives'.73

His lucid teachings allowed these monks to remain unified and thereby become a beacon in these turbulent times. To retain this status, they would have to learn and keep learning, and thus be able to guide others along the via regia as well.

The religious and educational function of monasteries in Medieval Western Europe has long been established in modern research. More work still needs to be done to fully comprehend the place of Smaragdus in the history and historiography of his community, and of the purpose of his writings - and the use he makes of his patristic source material - in the wider context of the Carolingian correctio-movement. However, the author of the Chronicle of Saint-Mihiel seems to have wanted to stress it was Smaragdus who formulated the importance of monasteries as part of the sacred foundations of the Carolingian Empire. As such, while it remains to be seen to what extent Smaragdus was representative for the Carolingian ecclesia as a whole, he did give his own community a clear sense of purpose that tried to steer a course between conservatism and reforming zeal by focusing on the learning that allowed the monks to become good Christians. Their function as 'managers of knowledge' has in a way disconnected the works of Smaragdus from an a priori (Christian) monastic identity that would be inextricably bound up with the (Christian) ideology of the Carolingians. ${ }^{74}$ Having done so, it has become possible to use the case of Saint-Mihiel as a background to an attempt to further our understanding of a type of community that is altogether more difficult to define. These are the hijras of medieval South Arabia - and it is to these hijras that we now turn.

\footnotetext{
73 Smaragdus, Expositio, c. 3: 'Monasterium enim, ut praedictum est, etiam unius monachi habiatio dicitur. Sed quaerendum est, si unius habitatio proprie monasterium vocatur, propter idioma Graecae linguae, qua dicitur monas unum, cur multorum habitatio in uno positorum monasterium dicatur, nisi forte, ut arbitror, propterea quia una fides, unum baptisma, cor unum et anima una est in omnibus bene et iuste viventibus monachis, sicut prius in religione recte credentium et bene viventium fuit'.

${ }^{74}$ On this ideology, see, in addition to Noble, 'Monastic ideal', also M. de Jong, 'Sacrum palatium et ecclesia: L'autorité religieuse royale sous les Carolingiens (790-840)', Annales: Histoire, Sciences Sociales 58.6 (2003), 1243-1269.
} 


\section{MANAGERS OF KNOWLEDGE: HIJRAS IN MEDIEVAL SOUTH ARABIA}

'A place in which there is something like a convent (khānaqāa) inhabited by worshippers and scholars (abl al- ilm)'.75

Starting from this explanation of what a Yemeni hijra is by the geographer Yāqūt al-Ḥamawī written sometime between 1212 and 1229 for his contemporary readership in the Levant, the following section will present a comparative case focusing on the institution of the bijra in medieval South Arabia (ca. 900-1300 AD) and how it was represented by some of their inhabitants. ${ }^{76}$

Far less research has been done on hijras than on monasteries in Europe. For our purpose, this is not necessarily a disadvantage, since it allows us to maintain enough distance to discuss how to actually conceptualize and understand what a bijra is. It is a case that is sufficiently different from the European one and can serve the purpose of Verfremdung. Thus it is highly comparable in the sense that it can provide us with new alternative understandings of 'enclaves of learning'. The aim is not to study one specific bijra, but rather to provide a generalized and representative overview of hijras in the medieval period with a focus on the management of knowledge in a way that is useful in a comparative perspective. The historical anthropological case has been written after having interacted with scholars of European medieval history and medieval monasticism and although the case may seem exotic for a Europeanist readership, it is intended to be clear also for historians in general and historians of European monasticism in particular.

The mountainous and slightly barren landscape of the highland plateau in the north western part of today's Yemen favoured religious communities and networks who operated within the existing tribal political landscape and who cooperated with various fragments of tribes or with local lords. The institution of hijra is thus distinctively tribal in that it could only exist in

\footnotetext{
${ }^{75}$ Quote and translation from W. Madelung, 'XIII: The origins of the Yemenite Hijra' [First published in: A. Jones (ed.) Arabicus Felix: Luminosus Brittanicus: Essays in Honour of A. F. L. Beeston on his Eightieth Birthday ,Ithaca 1991]," in Religious and Ethnic Movements in Medieval Islam (Ashgate, 1992). Khänaqäh is another word for a süfì lodge, zämiya or ribāt.

${ }^{76}$ This explanation if what a bijra is was found under Yāqūt al-Hamawī’s [1179-1229] entry of 'Waqash', which was the main hijra of the Mutarrifiyya in their mature phase before they were declared to be heretical and put down. Ismā'îl al-Akwa' (ed.), Al-Buldàn al-Yamaniyya 'inda Yàqüt al-Hamawì (Beirut, 1988), p. 301; Madelung, 'The Origins', p. 26.
} 
the form we know it in a tribal context, even though the inhabitants of the hijras saw themselves as fundamentally different from the tribal elites and communities. Similar 'enclaves of learning' in the Sunni lowlands of Yemen were rather called 'schools' (madrasas) or ribāt $\mathrm{s}^{77}$, and tended to be situated inside urban centres like Zabid. The actors in the madrasas did not depend on a genealogical defined community in the same way as did the Zaydis in their bijras. The Zaydi bijras also had a separate identity representing the Zaydi tradition or branch of Islam, while most schools in Lower Yemen were Sunni, thus being more integrated into the form of Islam followed by a majority of the people in the Islamic world at the time.

According to tradition, the first person to introduce Zaydism to the highlands of Yemen was Yahyaā b. al-Husayn in the year 897 AD. He came from the area around Medina in northwest Arabia, and claimed to be a descendent of the Prophet Muhammad. He initially settled as a mediator among the Khawlān tribes in the northern part of Yemen, but soon claimed to be the leader of the community of believers and took the imamic title 'al-Hādì ilā al-Haqq alMubīn' ('The Guide to the Clear Truth'). He set up a mosque and established an enclave of learning just outside the market town of Șa da. He took most of the northern highland south towards Sanaa through military campaigns, uniting some of the previously conflicting tribes in the process, if only for a short period.

After al-Hādī's death in 911, Zaydism was mainly confined to the area around Șa da where his descendants lived, and it was not until several centuries later that politically strong Zaydi charismatic rulers ('imams') appeared, along with a whole new class or stratum in society. Most of the Zaydi elite claimed to be descendants of the Prophet and that they therefore had a naturally elevated and authoritative role in terms of managing the Zaydi Islamic tradition of knowledge. Most explicitly, they were the only group out of which the imam could be recruited. At first, they were called Ashrāf (sing. Sharīf), sharaf originally meaning honour although in modern times they are called $S \bar{a} d a$ (sing. sayyid). One can say that they formed an elite in terms of religious knowledge, partly based on idealised genealogies of religious authority - something made all the more visible by the fact that they did not allow their

\footnotetext{
${ }^{77}$ For another comparative study on ribăts in the Islamic world, see H. Kennedy, 'The Ribāt in the Early Islamic World', in H. Day and E. Fentress (eds.), Western Monasticism Ante Litteram, (Turnhout, 2011).
} 
Rutger Kramer and Eirik Hovden

daughters to marry into the local Yemeni population. ${ }^{78}$

However, this form of elite Zaydism with strong political ambitions was not the only form that emerged after its initial introduction to the Yemeni highlands. In the years around 1050, or even before, we also see the start of a populist movement, largely consisting of local Yemeni tribesmen or low-status individuals. ${ }^{79}$ Seeking protection from local wealthy landowners, they set up their own enclaves of learning where they engaged in scholarly activities, discussions and rituals. Some of them were part-time members, and only came to visit certain times of the year. ${ }^{80}$

Those participating in the formation of these hijras were also represented as men of honour and personal quality (fadl), not because they were related to the Prophet by descent, but because of the merits they had earned by showing generosity and hospitality towards their fellow Zaydis/Muslims and because of their love for God, knowledge and fellow community members. At least, this is how they are presented in one of the main historiographical/hagiographical works written about their sect, composed around 1150 by one of the most prominent Zaydi scholars of his time, Musallam al-Lah.jī. ${ }^{81}$

The branch of Zaydis described by him was called the Muțarrifiyya after its alleged eponymic founder Muțarrif b. Shihāb, even though the movement had probably already existed in an early form before his appearance. ${ }^{82}$ These Muțarrifis usually called themselves Zaydis, probably to invoke the orthodoxy of their tradition, something that was often disclaimed by the Ashrāf-Zaydis, whom the Muțarrifis called al-Mukhtari a, after a theological concept much discussed at the time. ${ }^{83}$ It was the Muțarrifiyya who first set up enclaves of learning

\footnotetext{
${ }^{78}$ For a general history of the early medieval period see the unpublished thesis of D.T. Gochenour, The Penetration, $\mathrm{PhD}$ thesis, Harvard (1984).

79 These were the so-called Muțarrifiyya. See Wilferd Madelung, 'Muțarrifiyya', in P. Bearman, et al. (eds.), Encyclopaedia of Islam, New Edition, (1960-2004 [1992]); 'Alī Muḥammad Zayd, Tayyārāt mu'tazilat al-yaman fì l-qarn alsādis al-hijrì, (Sanaa, 1997); Gochenour, The Penetration of Zaydi Islam; 'Abd al-Ghanī Mahmūd 'Abd al-'Āțí, al-Sirā' alfikeri fì al-Yaman bayna al-Zaydìyy wa-l-Muțarrifiyya: Dirāsa wa-nușūṣ al-Haram, 2002).

${ }^{80}$ See the forthcoming article about the beginning of the Muṭarrifiyya by J. and E. Hovden. For members meeting at harvest time, see Abū al-Ghamr Musallam b. Muhammad b. Ja' far al-Lahjīi, Akhbär al-Zaydīya min abl al-bayt 'alayhim al-saläm wa-shì atibim bi-al-Yaman (MS no. 2449 Jämi at al-Imām Muḥammad b. Sa 'üd al-Islämiyya), p. 30, and pp. 634.

${ }^{81}$ Idem.

${ }^{82}$ Heiss and Hovden (forthcoming).

83 The name al-Mukhtari'a comes from the theological concept of ikhtiräa', (creation ex nihilo). See 'Alī Muhammad Zayd, Tayyārāt.
} 
explicitly called hijras, especially after $1100 .{ }^{84}$ Most of these were located in the areas west of Sanaa at a distance from the Zaydi imams who usually controlled the areas further north, especially after 1150. This explains how they were able to continue their activities, while opposing the Ashrāf-dominated Zaydis (al-Mukhtari' a) in doctrinal and theological matters. Eventually, however, the conflict between the Muțarrifiyya and the Imam al-Manșūr ' Abd Allāh b. Hamza (d. 1217) escalated to the point that he, after having them declared heretical in 1215-6, sent in his army to destroy their enclaves, and stop their activities altogether. After this decisive historical event, hijras were places only inhabited by Zaydi Ashrāf, and from then onward a hijra became synonymous with an enclave of ashräf population in an otherwise tribal context. ${ }^{85}$ Towards the end of the medieval period, several of these bijras increasingly became involved in the administration of the Zaydi theocratic state, although many of them also remained quite independent or even centres of opposition.

Most hijras had the term 'bijra' in the name, like Hijrat Waqash (meaning 'the Hijra of Waqash'). However, many of the early hijras were not explicitly called a hijra, and therefore it is problematic to define them as such. This especially applies to Ashrāf-dominated villages in the early period under scrutiny here. In those cases, one would have to look at other criteria, such as the presence of scholarly activities and the presence of protection agreements with the surrounding tribes to see if we can categorize them as hijras even if they are not called so in our sources. To complicate matters further, some hijras were hijras for a generation or two, but then took the appearance of a regular village of farmers populated by Ashraf. Oftentimes, the name-element bijrat would be dropped, whereas other villages called bijra today may not fit to the ideal type of an enclave of learning as defined in our comparative project. Again, contextualization as well as awareness of time, place and circumstance is of the essence.

From this short historical overview, at least four criteria or characteristics for a hijra emerge:

1. A village as a protected enclave in agreement with surrounding tribes

2. Inhabited by Ashrāf/Sāda (but not so for the hijras of the Muțarrifiyya)

3. Centres of religious-scholarly activity

4. That such settlements were explicitly called a hijra at a point of time, for example

\footnotetext{
84 This point is elaborated by Madelung in The Origins.

85 The exception to this are hijras inhabited by Zaydi scholarly families not descending from the Prophet, the so called fuqahä' or qudāh ('jurists'). Examples of this are well known from more recent periods.
} 
'Hijrat Waqash'.

Not all of these four criteria would always be fulfilled in the period under scrutiny. Some historians, such as Ismā' $\overline{1}$ al-Akwa' , tend to emphasise aspects of learning and managing knowledge when writing about the history of hijras ${ }^{86}$, while for other historians the Zaydi identity is a more important feature. Moreover, the idea that the inhabitants of a bijra set themselves outside the tribal system by establishing a 'de-militarized' zone devoted to scholarly activities exclusively is also problematic; many $A s h r \bar{a} f$ settlements were not neutral enclaves, and many were involved in local armed conflicts. A tribal meeting ground, market, scholar, mediator or shaykh can also be declared to have hijra status of protection, but this phenomenon would only partly fit with the phenomenon we want to describe here. ${ }^{87}$ Thus, the limits of our proposed definition are not absolute. Depending on which phenomena we are want to represent, we can and should keep the definition open and flexible, with several alternative ideal types in the middle.

Using 'Enclaves of Learning' as a tool, even more questions can be raised about life in these hijras and the visions of community the inhabitants promoted. One of the most central notions was the focus on (Islamic) learning and the study and upkeep of this vast written culture. Inhabitants of hijras engaged in a wide range of scholarly and religious activities. Some of these were institutionalised through foundations (waqf), which offered salaries for teachers and scholarships for students. ${ }^{88}$ But probably, most of these activities were informal and based on loose networks, and on patronage from wealthy individuals, especially in the early history of the Mutarrifi-Zaydi hijras of the mediaeval period. Some of the scholars were local inhabitants living with their families; others were travelling around to various bijras.

\footnotetext{
86 Ismā 'ìl b. 'Alī al-Akwa', al-Madāris.

87 See Puin, The Yemeni Hijra Concept.

${ }^{88}$ So far, we only have few examples of endowments and foundations (waqf) from the early medieval period in the Zaydi areas of Yemen, only much later, from the Ottoman (after around 1550) and following Qāsimī period do we know with certainty that waqf was common. The important Yemeni historian Ismā'il al-Akwa' only found two schools (madäris) in the northern Zaydi areas referred to as 'schools' in his seminal work on madrasas in Yemen, namely Madrasat al-Shāhil and Madrasat Rạ̣bat al-Sūd. He relates that the important scholar Humayd b. Aḥmad alMuhalli donated foundations of land (waqqafa amwāl) for these two schools and that he died in 1254. al-Madaris pp. 135-6. Perhaps his father was the al-Faqīh Ahmad b. Muhammad al-Muhalli who, on the order of the imam alManșūr 'Abd Allāh b. Hamza, was sent to teach at the madrasa in the Muṭarrifi bijra Hijrat Qā'a in the year 1206-7. Abū Firās b. Di tham, Al-Sìra al-sharifa al-Manșüriyya: Sìrat al-Imām 'Abd Allāh b. Hamza 593-614 H (ed.) 'Abdul Ghanī Maḥmūd 'Abd al- Āṭī. (Beirut, 1993), vol 2 p. 965. In the coastal Sunni areas, however, related to the madrasas, we can see foundation documents (waqfiyyat) being made with very specific stipulations concerning how the school should be equipped and managed. A mere example of an elaborate foundation document is the waqf document from 1545 for the foundation of the Madrasat al-Nizāāī in the town of Manzil Hassān, near Hụṣn alHabb in Ba'dān north east of Ibb. The text of the waqf document is edited by al-Akwa': Al-Akwa', al-Madäris alislämiyya, pp. 351-57.
} 
When a hijra was a village of Ashräf population, we must also assume that most of the individuals were not experts in religious knowledge but rather engaging in agriculture, not to mention their families including women and children. From ethnographic evidence from more recent periods we know that within or near hijras there could also be low status individuals and families who performed work considered demeaning for the Ashräf. The internal social sphere in most hijras was thus much larger that the circle of student and teachers active there: a hijra was often more of a full-scale village, including activities and institutions of learning, rather than the school only.

Al-Akwa' writes that few Zaydi madrasas (schools) existed, or at least that this term was not employed all that often. For him and for many other historians, a madrasa came to mean a Sunni institution while in the Zaydi areas the scholarly activities took place in hijras. One example of the few Zaydi madrasas was Madrasat Sharaf al-Dīn at Kawkabān which was built shortly after 1500. However, this madrasa was not like the grand and elaborate schools founded by the elites of the Rasūlid or Ṭāhirid dynasties in Sunni, Lower Yemen; this was more a local mosque that happened to be called a madrasa, according to al-Akwa' ${ }^{89}$ In Lower Yemen, we know of madrasas being founded already from the time of the Ayyubid occupation of 1197-98 and onwards. ${ }^{90}$ Some few Zaydi madrasas were later built in cities and urban areas such as Sanaa and Dhamār by Imam Sharaf al-Dīn (r. 1506-55). ${ }^{91}$ Still, scholarly activities in the rural Zaydi north was mainly confined to numerous small hijras where there was usually no specific building or institution called madrasa, but where schooling probably mostly took place in the local mosque or reception rooms, supported financially by donations from wealthy families and/or through foundations (waqf) for that purpose, and probably managed by the guardian (mutawali) of the local mosque. ${ }^{22}$

Most students in the bijras probably only learned how to read and write, to recite the Quran and the basics of Islamic law. Only educated individuals engaged in high-level discourses of philosophy, theology, history and wrote legal and exegetical commentaries. Sometimes this

\footnotetext{
89 al-Akwa', al-Madāris al-islämiyya fi-l-Yaman, p. 360.

${ }^{90}$ Ibid., p. 6.

${ }^{91}$ For the al-Madrasa al-Shamsiyya built in 1541 in Dhamār , see al-Akwa', Ibid., p. 370. The Madrasat Sharaf al-Dīn in Sanaa was built in 1554-55, see Ibid., p. 365.

${ }^{2}$ Schmidtke also mentions that the Imam al-Mahdī Ahmad b. al-Husayn (d. 1258) when he was young, was enrolled in the Madrasat Mislit (or Maslit )in Banū Qays (probably Banū Qays in today's Banū Șuraym, Hāshid. This is one example of a school being called madrasa at that time that al-Akwa' did not mention. Sabine Schmidtke, 'The literary-religious tradition among 7th/13th century Yemenī Zaydīs: The formation of the Imām al-Mahdī li-Dīn Allāh Aḥmad b. al-Husayn b. al-Qāsim (d. 656/1258)', Journal of Islamic Manuscripts 2 (2011), p.175.
} 
Rutger Kramer and Eirik Hovden

high-level discourse took political dimensions when different political elites supported various fractions of theologians and these theological differences were re-moulded into populist slogans and made more generally understandable, as for example during the many debates around the years 1150-1200 on the topic on natural or divine causality. ${ }^{93}$

Important historical sources from this time are biographies of various Zaydi imams, in addition to the already mentioned biographically arranged history of the Mutarrifiyya sect written by one of its main leaders, Musallam al-Lahjī (probably died in 1150). His work describes various members of this local, bottom up form of Zaydism, which started roughly a century and half before his writings. ${ }^{94}$ Of course, he did not claim that this sect only started then: in the first volume ${ }^{95}$ he begins with the first Zaydi imams in Yemen, al-Hādī and his two sons and throughout his work he emphasises that the 'Zaydis of Yemen', as he called his own sect, were founded on Zaydi orthodoxy, especially in the doctrines of the first imam who introduced Zaydism to Yemen in 897, al-Hādī ilā al-Haqq. The hijras mentioned in alLahjī's work are places where pious individuals, students and teachers of the religious sciences, and worshippers could meet and stay together, but without the strict laws and rules we know from European monastic culture. For al-Lahjī̄, personal piety, hospitality and sharing of wealth were the first order personal qualities ( $f a d l$ originating, and manifesting themselves in, love for God, love for knowledge and the fellow Muslims. According to him, living together in confined hijras was not the only way of being a good Muslim, but it was a good place to practice and engage with the faith and to keep contact with the fellow believers.

By describing the sect members in this way, al-Lahjī also created a counter-discourse to the genealogy based (nasab) honour of the Ashrāf Zaydis and their imams. For instance, through his use of narratives attested by chains of transmissions and sect members, he 'documented' that the earlier members of the Mutarrifiyya had the piety, hospitality, wisdom and

\footnotetext{
${ }^{93}$ For a description of the doctrinal 'battle' between the Muțarrifiyya and the Mukhtari 'a Zaydis, see: Jan Thiele, Theologie in der jemenitischen Zaydiyya: die naturphilosophischen Überlegungen des al-Hasan ar-Rașsāṣ (Leiden, 2013); Zayd,

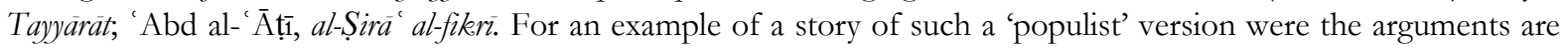
made understandable for others than experts, see the story about hail in al-Sira al-sharifa al-Manșüriyya vol. 2, pp. 85253.

${ }^{94}$ al-Lahjī, Akhbär al-Zaydīya. The most important of his extant works is the fourth volume, in which he describes members of the Mutarrifiyya and their lives and acts since around 1000 until his own time.

95 A fragment of the first volume is extant and a large part about Imam al-Nāṣir Aḥmad b. Yaḥyā b. al-Ḥusayn is edited by Madelung: Musallam al-Lahjīi, The Sïra of Imām Aḥmad b. Yahyā Al-Nāṣir li-Dìn Allāh; From Musallam alLahjī's Kitäb Akhbār Al-Zaydiyya bi l-Yaman, (ed.) Wilferd Madelung (Exeter, 1990).
} 
knowledge to exist in their own right, based on individually achieved merit rather than on descent from the Prophet. Especially radical was his assertion that low-status individuals with demeaning jobs could have good personal qualities. Thus, he gives us a unique insight into the social history of that time - especially so in the vivid descriptions of the 'enclaves of learning' that were so important to his sect.

\section{CONCLUSION: A SENSE OF WONDER}

The two case studies presented in this article not only demonstrate the differences between, for instance, Arabian and European 'enclaves of learning', but also the different approaches and methodologies used by each of the co-authors - which in turn showcases the advantages of a comparative approach involving multiple specialists in their respective fields. ${ }^{96}$ The broad approach to the study of hijras, necessitated by the fact that these communities and the texts they produced are still a largely untapped phenomenon in the field of South Arabian studies can be streamlined by observations made from the study of European monasticisms, where cultural familiarity and long-standing academic traditions allow researchers a relatively high level of sensibility towards questions of community formation and consolidation, as well as regarding the interplay between idealism and pragmatism as evidenced by the sources. ${ }^{97}$ On the other hand, the Verfremdungseffekt created by the comparison with the South Arabian enclaves presented here have caused helpful creative tensions which enabled the researchers to re-evaluate their own preconceived notions both on an emic and an etic level.

The comparative process may teach participants not only about the object they study, but also about the methodologies they employ. ${ }^{98}$ The fact that the community Saint-Mihiel, and especially its abbot Smaragdus, had its roots in a context where learning and self-reflection were seen as important qualities for their sort monastic endeavour further emphasise this

\footnotetext{
${ }^{96}$ I. Vallier, 'Empirical Comparisons of Social Structure: Leads and Lags', in I. Vallier (ed.), Comparative Methods in Sociology: Essays on Trends and Applications (Berkeley 1971; 2nd edition 1973), pp. 203-65, at pp. 211-15. Needless to say, this approach requires an active participation and excellent record-keeping.

${ }^{97}$ W. Pohl, 'History in Fragments: Montecassino's Politics of Memory', Early Medieval Europe 10 (2001), pp. 343-74 for both a methodological approach and a case study showing how this functioned on a pragmatic, communal level. 98 J. Hort, 'Vergleichen, Verflechten, Verwirren: Vom Nutzen und Nachteil der Methodendiskussion in der wissenschaftlichen Praxis - ein Erfahrungsbericht', in A. Arndt, J.C. Häberlen and C. Reinecke (eds.), Vergleichen, Verlchten, Verwirren? Europäische Geschichtsschreibung zwischen Theorie und Praxis (Göttingen, 2011), pp. 319-41, draws a similar conclusion but attaches altogether more pessimistic consequences to it.
} 
Rutger Kramer and Eirik Hovden

point. Rather than considering Saint-Mihiel to be an enclave of learning representative for the general intellectual climate at the time, however, the insights that Smaragdus - and, more importantly, his representation in the Chronicon several centuries later - first and foremost elucidate ways in which the community was aware of itself as an enclave of learning. More research is definitely needed to extend these observations to a larger early medieval European context, by comparing these initial observations to depictions from other cases in the same cultural sphere.

The description of the hijras in the second case study relies on generalised hypotheses and models of how we can see the Yemeni medieval hijras in a comparative light. These generalisations have, in turn, been guided by 'learning' as a theme. The problem of how to define the medieval hijras and classify them could only be touched upon briefly here and indeed much more research is needed before one reaches the level attained by researchers of European medieval monasticism. For now, however, a level of abstraction and generalisation was unavoidable. Still, once a certain point of Verfremdung is reached, we can study hijras as 'enclaves of learning'. The questions posed by European medieval scholars of their sources may help guide further research into the question what a hijra was, and how it was understood and communicated by various authors and actors at the time as well as in subsequent centuries.

The discrepancy between the levels of community in the case studies presented may hamper our ability to draw conclusions applicable to both cases. It is, after all, difficult to identify commonalities and differences based on a close reading of the source material emanating from a single monastic community on the one hand, and a contextualized overview of the developments of regional religious communities and their institutions on the other. However, this ought not to be the ultimate aim of cross-cultural comparative studies. Any similarities that do occur, as far as they have not served as the basis for the comparison in the first place, should be the basis for further questions in the specific fields rather than the start of a search for the lowest common denominator, which would lead to conclusions that are so broad as to become meaningless. If anything, multi-angled, qualitative comparative research should make people more sensitive to the vicissitudes of contextualization and generalisation, and sharpen the edge of local social logics instead of grinding them down.

The goal of our enterprise has not been to define 'enclaves of learning' in a way applicable to 
all cultures, and it should also be noted that this conceptualization has been tailor-made to suit the needs of this particular comparative study. ${ }^{99}$ As a soft concept, it has proven useful to bounce ideas off and formulate new questions concerning the many 'shades of meaning' involved in explaining the existence and function of the communities studied in Europe and Arabia. ${ }^{100}$ For instance, the concept has proven useful to re-appraise the function of monastic communities in Europe in the face of ever-changing religious reform movements throughout the early and high Middle Ages, which in turn led to a bewildering diversity of different communities hidden under the guise of 'orders', 'monasticism' or other broad and abstract concepts. Using the idea of an 'enclave' to make them comparable also helps bridge the gaps between the ideology they represented in the sources they produced and the pragmatic considerations they had when inscribing them. Conversely, describing these communities in terms of guarding, fostering and communicating knowledge and teaching(s) will allow students of hijras to regard them as the permeable enclaves they were, and not merely as a network of teachers. More generally, it has allowed participants to go beyond the dichotomy of communities either reacting against or acting in conformity with their surroundings. It has created a more acute sensitivity to the possibilities and shortcomings of the sources used, which were themselves the product of compromises - they were part of negotiations between the different levels of community that come together in enclaves of learning. Like the comparative method itself, they show the fluidity and multiplicity of the concepts that have acquired a much more static, high-threshold meaning in individual disciplines operating in isolation.

On a methodological level, 'enclaves of learning' represent the need for a certain awareness required for every trans-disciplinary comparative enterprise. Awareness of the starting point of the research, for example - whether to begin from a community within a larger framework of conflicting ideologies and practices, or to start from an ideal type and see whether individual communities measure up to it. ${ }^{101}$ Far from attaining a compromise, it is

\footnotetext{
${ }^{99}$ D. Rueschemeyer, 'Can One or a Few Cases Yield Theoretical Gains?', in Mahoney and Rueschemeyer (eds.), Comparative Historical Analysis, pp. 305-36 points out the weaknesses of using only a limited number of cases, which according to him leads to 'virtually insurmountable obstacles' to obtaining usable comparative results. However, his underlying assumption is that comparative research should ideally lead to 'a universally applicable social theory', whereas the goal of this article is to make more theoretical gains and possibly prepare the way for a more substantial comparative analysis of our 'enclaves of learning'.

100 A.A. van den Braembussche, 'Historical Explanation and Comparative Method: Towards a Theory of the History of Society', History and Theory 28 (1989), pp. 1-24, at p. 24.

101 A problem that already occupied Max Weber: N.J. Smelser, Comparative Methods in the Social Sciences (New Orleans, LA, 2013), pp. 114-50. Cf. B. Rosenwein, 'Theories of Change in the History of Emotions', in: J. Liliequist (ed.), $A$ History of Emotions, 1200-1800 (London 2012), pp. 7-20, esp. at pp. 7-8, for a similar challenge in the study of
} 
Rutger Kramer and Eirik Hovden

important to allow for a concept that enables researchers to look in either direction. Additionally, it should also help to remind all those involved that that every discipline is inherently idiosyncratic and relies on long and valuable traditions. ${ }^{102}$ In order to reach a situation in which the comparative researchers can communicate on an equal footing, a dialogue must be established. At its most basic level, 'enclaves of learning' is not an answer to the question of what is being compared, but part of the question itself, intended to spark debates about what is studied in the first place. ${ }^{103}$ In the process, the idea is to lower the walls between disciplines instead of erecting a conceptual labyrinth.

The point is to not look at borders around our (and our subjects') categories, but to try to see how these borders are constantly breached and crossed in pragmatic ways often contrary to the ideal. This is why we need etic and analytical terms to describe what we see, which does not fit with what should have be seen in the first place. Verfremdung consists of the language of analysis and etic descriptions we use to make our study of objects comparable, and it is through interdisciplinary debates and discussions that researchers may keep the distance to their study objects that is necessary to compare them. As such, a comparative project such as this, which almost forces its participants into a state of Verfremdung, is also about rediscovering one's own subject, reappraising one's own discipline, and re-establishing a sense of wonder about the world behind the sources. The authors strive to be sensitive to similarities without taking them at face value, and acquaint themselves with different discourses before starting our mission. 'Enclaves of learning' still have something to teach us.

emotions.

102 As already noted by J.T. Flint, 'Conceptual Translations in Comparative Study: A Review Article', in: Comparative Studies in Society and History 18 (1976), pp. 502-16, esp. pp. 512-13.

103 Cf. C. Lutter, 'Comparative Approaches to Visions of Community', in: Gingrich and Lutter (eds.), History and Anthropology (forthcoming). 